\author{
Research article \\ urn:lsid:zoobank.org:pub:C8B84FD5-C191-4228-9CC9-9CBB4F8A0C68
}

\title{
New and poorly known giant scale insects (Homoptera: Coccinea: Margarodidae s. lat.) from the Oriental region with taxonomic and nomenclatural notes on the subfamily Monophlebinae
}

\author{
Ilya A. GAVRILOV-ZIMIN \\ Zoological Institute, Russian Academy of Sciences, 1 Universitetskaya Emb., \\ St. Petersburg, 199034, Russia. \\ Email: coccids@gmail.com \\ (1) https://orcid.org/0000-0003-1993-5984 \\ urn:Isid:zoobank.org:author:9AED29CB-C4CC-4AB2-8905-437FEB363745
}

\begin{abstract}
A new scale insect genus and species, Gompholopium quercicola gen. et sp. nov. is described and illustrated, based on material from China (Yunnan Prov.). Hemaspidoproctus cinereus (Green, 1922 ) is redescribed, based on material from India (Allahabad). Walkeriana tosariensis Reyne, 1957 is transferred to the genus Hemaspidoproctus Morrison, 1927 - H. tosariensis (Reyne, 1957) comb. nov. Monophlebus neglectus Gavrilov-Zimin, 2018 syn. nov. is formally synonymized with the unrecognizable Monophlebus atripennis Burmeister, 1835 in order to resolve an old taxonomic and nomenclatural problem in the subfamily Monophlebinae.
\end{abstract}

Keywords. Scale insects, monophlebines, morphology, new species.

Gavrilov-Zimin I.A. 2021. New and poorly known giant scale insects (Homoptera: Coccinea: Margarodidae s. lat.) from the Oriental region with taxonomic and nomenclatural notes on the subfamily Monophlebinae. European Journal of Taxonomy 746: 50-61. https://doi.org/10.5852/ejt.2021.746.1317

\section{Introduction}

The subfamily Monophlebinae Signoret, 1875 is one of the most difficult for taxonomic studies amongst all scale insects. The members of this subfamily are usually large insects (up to $4 \mathrm{~cm}$ long), which primary live on twigs and branches of tropical and subtropical plants (Morrison 1928; Foldi 2016; GavrilovZimin 2018). Some species, for example most of Iceryini Cockerell, 1899, are widely distributed and form dense colonies on their host plants, whereas the species of most others genera (from the tribes Monophlebini Signoret, 1875, Monophlebulini Morrison, 1927, Labioproctini Gavrilov-Zimin, 2018, and Drosichini Morrison, 1927) are comparatively rare or very rare; usually they do not form colonies and are represented in the scientific collections as occasional specimens only. The large size of these insects often impedes the preparation of Canada balsam slides for microscopic study of the minute morphological structures, used as taxonomic characters in coccidology. On the other side, the presence of numerous setae and variable wax pores on the body of monophlebines significantly complicates the preparation of the standard total drawings of the mounted specimens. Many species of Monophlebinae were described in the $19^{\text {th }}$ and first half of the $20^{\text {th }}$ centuries, without preparing microscopic slides and 
without a description of any minute structures. This fact, as well as the description of some species based on the male characters only, resulted in a situation with a number of species practically unrecognizable and keeping the status of nom. dub. This is especially problematic in the genera where unrecognizable species were designated as the type species. The most famous and deplorable example is Monophlebus atripennis Burmeister, 1835, presently unrecognizable (see discussion in Gavrilov-Zimin 2018: 153), whereas this species is the type for Monophlebus Guérin-Méneville, 1827 and, correspondingly for the tribe Monophlebini and entire subfamily Monophlebinae. Without understanding the morphology of this species, it is impossible to provide exact taxonomic definitions of all higher rank categories and, as a result, it is impossible to place correctly new taxa of Monophlebinae in the appropriate subfamily. This publication intends to resolve this old impediment.

Some additional nomenclatural instability arises from the fact that the family-group name Monophlebites Signoret, 1875 as well as Porphyrophorites Signoret, 1875 and Xylococcinae Pergande, 1898 have a nomenclatural priority over the commonly used family-group name Margarodidae Cockerell, 1899. Williams (1969) was the first who discussed this problem. Koteja (1974) even used Porphyrophoridae as a valid name one time, but in the subsequent papers (for example, Koteja 2000 and further) he again used Margarodidae as a valid name. Danzig (1980) noted the need to apply to the International Commission on Zoological Nomenclature for protecting the name Margarodidae for the purpose of nomenclatural stability and then Foldi (2005) repeated the same idea, but until now, no application has been submitted (D.J. Williams, pers. com. and my own information). However, after 1999 the new rule is accepted in the International Code of Zoological Nomenclature (ICZN) for such situations (Article 35.5). According to this article, the recent revision of the higher taxa of archaeococcids (Gavrilov-Zimin 2018) continued to use Margarodidae as a valid name. The present paper also follows this approach. The other names of higher taxa as used below are following the latest revision of the family by Gavrilov-Zimin (2018).

\section{Material and methods}

The adult females of the species described and redescribed below were collected in China and India by the Russian entomologists N. Borchsenius and N. Alexandrov in 1957-1958; the collecting data are provided below. The method of preparation of the Canada balsam slides is described, for example, in Gavrilov-Zimin (2018).

All studied material, including types, is deposited in the Zoological Institute of the Russian Academy of Sciences (ZIN RAS) (St. Petersburg, Russia). The numbers with ' $\mathrm{K}$ ' refer to the unique collecting numbers for both ethanol preserved or dry material and Canada balsam slides.

\section{Results}

\section{Taxonomy}

Class Insecta sensu Leach, 1815 (non Linnaeus, 1758)

Order Homoptera sensu Westwood, 1838 (non Latreille, 1810)

Family Margarodidae Cockerell, 1899

Subfamily Monophlebinae Signoret, 1875

Tribe Monophlebini Signoret, 1875

Genus Monophlebus Guérin-Méneville, 1827

Monophlebus atripennis Burmeister, 1835

Monophlebus neglectus Gavrilov-Zimin, 2018: 159, figs 9.4.6-9.4.7. Syn. nov. 
Remarks (the taxonomic notes published in Gavrilov-Zimin 2018: 153 on this subject are partly reported here for clarity)

Monophlebus, the type genus of the tribe Monophlebini, was originally introduced in the coccidological literature by Guérin-Méneville (1827) who did not include any species in this genus, but provided a diagnosis: "Genre de 1'ordre des Hémiptères, section des Homoptères, famille des Gallinsectes, établi par Latreille (Familles Naturelles du Règne Animal) et dont il ne donne pas les caractères; il dit seulement qu'il diffère des Dorthésies et des Cochenilles, parce que les antennes sont moniliformes et composées d'environ vingt-deux articles" (Guérin-Méneville 1827: 99). Obviously, Guérin-Méneville mentioned male characters, because most of Monophlebinae males have "antennes ...moniliformes" in contrast to all known females. The first species of Monophlebus were described 8 years later by Burmeister (1835), who provided very brief and incomplete descriptions of the males of $M$. atripennis Burmeister, 1835 from Java (Indonesia) and M. fuscipennis Burmeister, 1835 from Germany. The type specimens of both these species were lost. Cockerell (1902a: 232; 1902b: 317) designated and discussed M. atripennis as a type species of genus Monophlebus, in spite of the absence of any characters for identification of this species. Reyne (1965) conducted an extensive study of Monophlebinae males, collected from Java, but was unable to identify M. atripennis. Moreover, scale insect systematics and identification is mainly based on female characters, whereas females of $M$. atripennis are unknown at all. So, an unambiguous identification of M. atripennis is not possible until now. The second species of Burmeister, M. fuscipennis, was transferred by Cockerell (1894) to his genus Palaeococcus Cockerell, 1894. Later Cockerell (1902a: 233) designated M. fuscipennis as the type species of the genus. Several taxonomists (Westwood 1845; Hempel 1920; Vayssière 1932) described additional species in the genus Monophlebus from other regions of the world, but not from Java! All these descriptions are also incomplete or even based on male characters only.

In order to resolve this very old problem, Gavrilov-Zimin (2018: 153) suggested to use the only properly described species of Monophlebus, M. neglectus Gavrilov-Zimin, 2018, collected in Java, as the new type species of the genus. However, the replacement of the type species could only be accomplished with the used of the plenary power by the International Commission on Zoological Nomenclature (Art. 81.1). Before the application to the ICZN, the type specimen for each involved species (the older type species and a newly proposed type species) have to be fixed. Since the type of Monophlebus atripennis is lost, an alternative solution was suggested by one of the ICZN commissioners (D.A. Dmitriev, Illinois Natural History Survey, USA, pers. com.). A neotype could be designated for Monophlebus atripennis, and if this type specimen is, at the same time, the holotype of Monophlebus neglectus, this would establish the objective synonymy between two species names. Following this recommendation, I here designate the holotype specimen of Monophebus neglectus also to be the neotype of Monophebus atripennis, establishing the formal synonymy between the two names. The neotype label data are: adult female, K 1301-a, Indonesia, Java, "Buitenzorg” [Bogor], 1907, host plant and collector's name unknown. The neotype is deposited in the Zoological Institute, Russian Academy of Sciences.

Genus Gompholopium gen. nov.

urn:1sid:zoobank.org:act:99E62D80-CF7C-4BC2-A385-F91F9EAB7D05

Figs $1-2$

\section{Type species}

Gompholopium quercicola gen. et sp. nov.

\section{Diagnosis}

The new genus differs from all other genera of the tribe Monophlebini in the presence of lanceolate conical setae, densely covering the body and in the presence of the discoidal wax glands with stalked centre. 
Morphologically, the new genus seems to be the most similar to the Palaearctic Pseudaspidoproctus Morrison, 1927 and Nearctic Llaveiella Morrison, 1927 in the presence of numerous conical setae (see the figure and the key for genera in Gavrilov-Zimin 2018: 154, 158).

\section{Etymology}

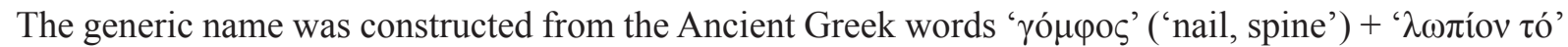
('clothes'), the gender is neuter.

\section{Description}

\section{Adult female}

Body broadly oval, covered by solid wax plates (Fig. 1). Antennae 9-segmented. Legs normally developed; claw without denticle; claw digitules short, setose. Mouthparts well developed. Abdominal spiracles numbering 7 pairs; each abdominal spiracle with unilocular atrium, without wax pores inside or just near spiracular atrium. Anal apparatus represented by a short tube with internal sclerotized anal ring. Fifteen round cicatrices forming semicircle on abdominal sternites. Wax glands represented by four main types of discoidal wax glands: 1) variable pores with stalked centre; 2) usual multilocular pores with round or oval central loculus and 10-12 peripheral loculi; 3 ) irregular multilocular pores with multiform central loculus and 6-10 peripheral loculi; 4) simple pores. Conical setae very numerous, with more or less lanceolate apices. Flagellate setae of different size and thickness numerous.

\section{Male and larval instars}

Unknown.

Gompholopium quercicola gen. et sp. nov. urn:1sid:zoobank.org:act:9A7B1ED4-F9B1-4F36-AD5D-3AE8F0D2B144

Figs $1-2$

\section{Etymology}

The species name was constructed from the Latin name of the host plant, Quercus sp. + the Latin suffix 'cola', meaning 'inhabitant of'.

\section{Material examined}

\section{Holotype}

CHINA • क; Yunnan, 70 km S of Jingdong; 25 Mar. 1957; N. Borchsenius leg.; on twigs of Quercus sp.; ZIN RAS, K 1548.

\section{Paratypes}

CHINA • 11 dry 우우 ; same collecting data as for holotype; ZIN RAS, K 1548.

\section{Description}

\section{Adult female}

Body broadly oval, up to $4 \mathrm{~mm}$ long, covered by solid wax plates (Fig. 1). Antennae 9-segmented, covered by flagellate setae of different sizes; some of the antennal segments bearing minute setae, which represent, probably, any kind of sensilla. Legs normally developed; trochanter with 3 sensilla on each face; claw without denticle; claw digitules short, setose. Mouthparts well developed. Thoracic spiracles with spiracularia. Abdominal spiracles numbering 7 pairs, located along abdominal margin on dorsum; each abdominal spiracle with unilocular atrium, without wax pores inside or just near spiracular atrium. Anal apparatus represented by a short tube with internal sclerotized anal ring. Fifteen round cicatrices forming semicircle on abdominal sternites. With four main types of discoidal wax glands: 1) variable 
pores (each about 7-10 $\mu \mathrm{m}$ in diameter) with stalked centre and with $2-5$ peripheral loculi, scattered on all body surface, but more numerous in marginal zone of venter; 2) usual multilocular pores (each about $10 \mu \mathrm{m}$ in diameter), with round or oval central loculus and 10-12 peripheral loculi, grouped around anal opening on dorsum, around vaginal opening on venter and scattered in medial and submedial zone of abdominal sternites; 3) irregular multilocular pores (each about 7-10 $\mu \mathrm{m}$ in diameter), with irregular central loculus and 6-10 peripheral loculi, forming group around anal opening on dorsum, group around vaginal opening on venter and scattered in medial and submedial zone of abdominal sternites; 4) simple pores (each about $2 \mu \mathrm{m}$ in diameter), scattered in medial zone of ventral thorax. Conical setae very numerous, with more or less lanceolate apices, scattered on all dorsum and in marginal zone of venter. Flagellate setae of different size and thickness numerous in medial and submedial zone of ventral cephalothorax, on abdominal sternites. Long hair-like setae sparsely scattered on dorsum and in marginal zone of venter among conical setae.

\section{Male and larval instars \\ Unknown.}

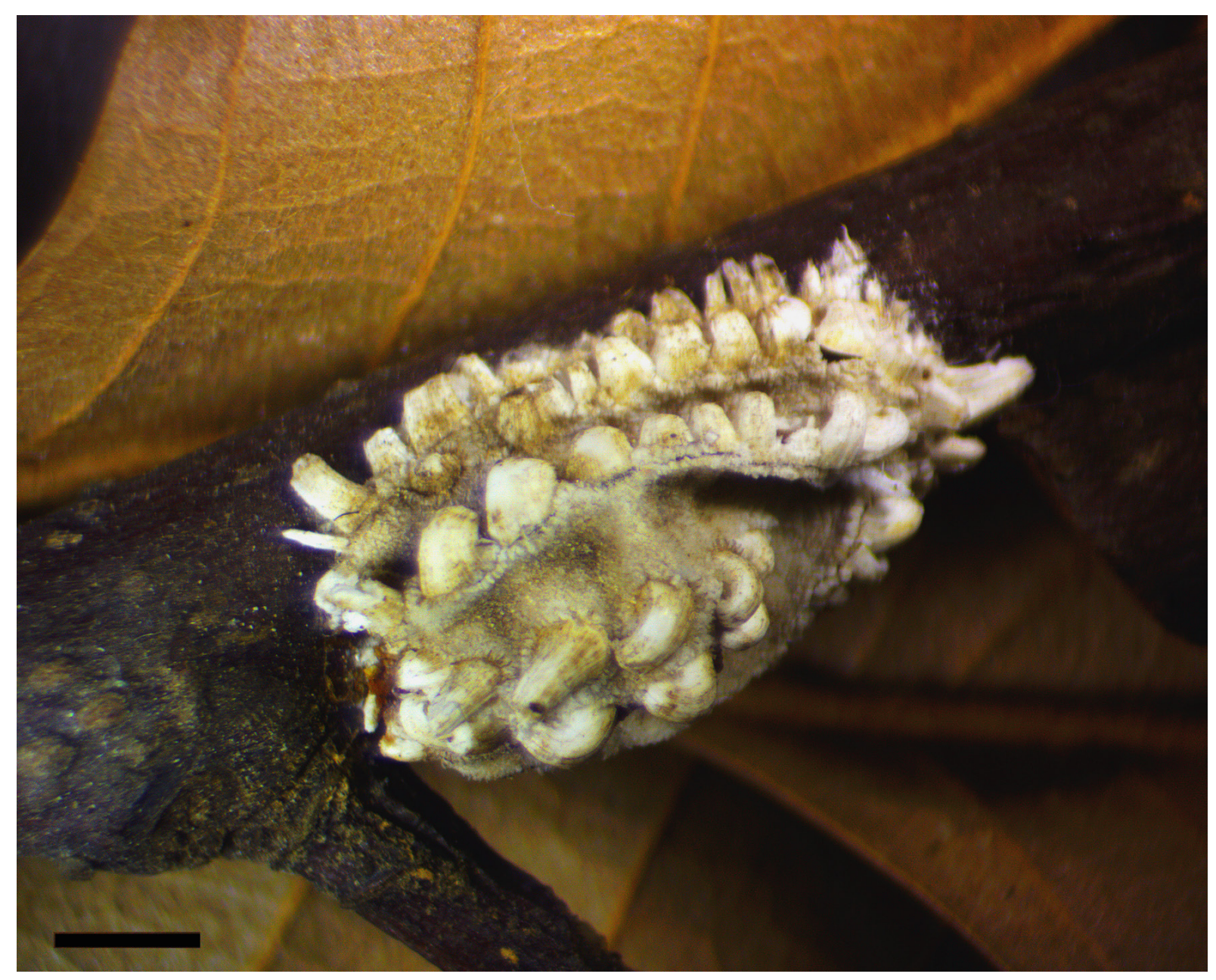

Fig. 1. Gompholopium quercicola gen et sp. nov., paratype, dry ${ }_{+}$(ZIN RAS, K 1548) on twig of host plant. Scale bar $=1 \mathrm{~mm}$. 


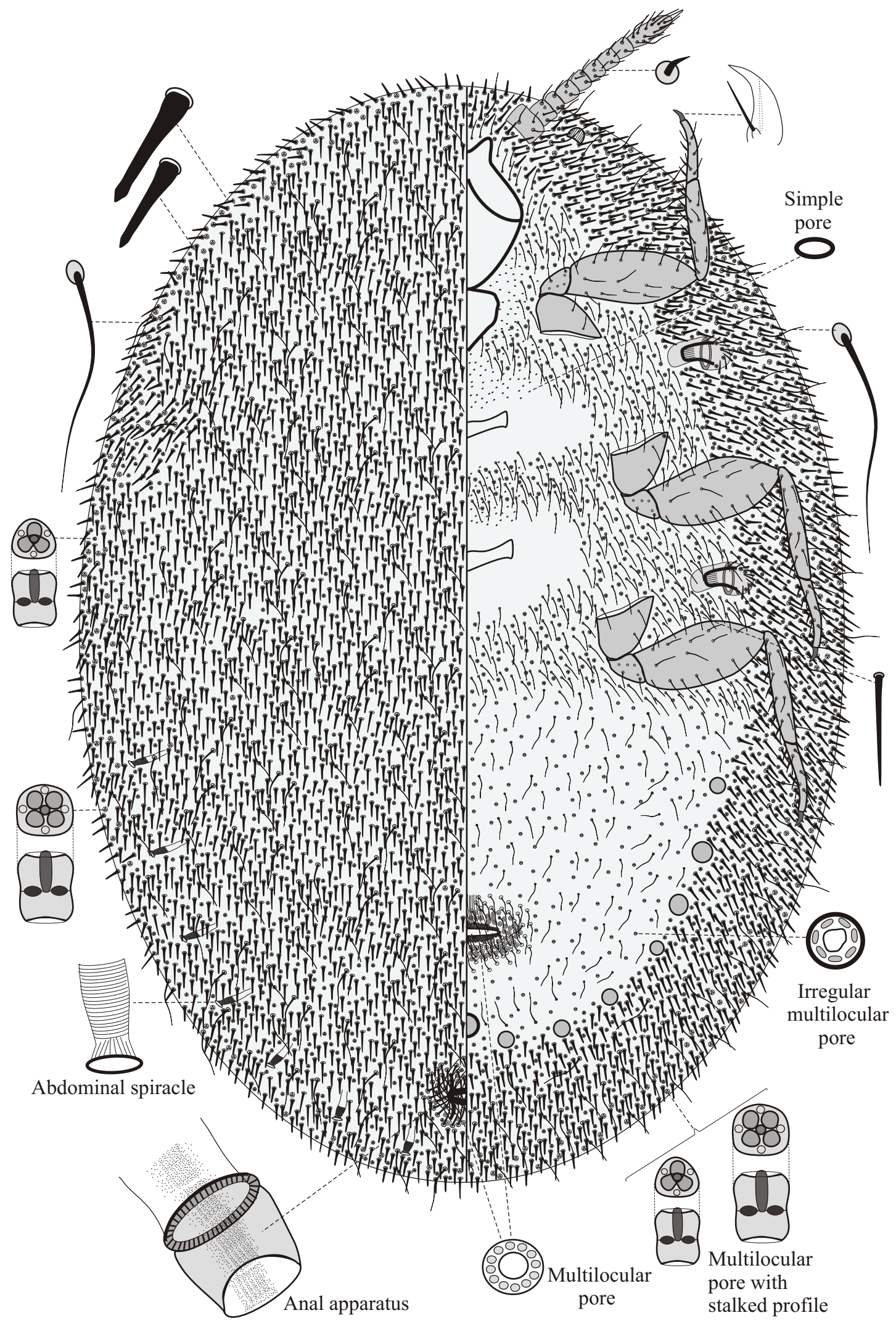

Fig. 2. Gompholopium quercicola gen et sp. nov., holotype, adult $q$ (ZIN RAS, K 1548). Morphology. Not to scale. 


\section{Remarks}

The species is probably marsupial, according to the shape of abdomen of the available very young females.

Tribe Labioproctini Gavrilov-Zimin, 2018

Genus Hemaspidoproctus Morrison, 1927

\section{Remarks}

Morrison (1927: 104; 1928: 148) provided a description of this genus, based on its type species, Aspidoproctus cinerea Green, 1922. However, neither this description nor the original description by Green (1922: 450) were accompanied by the total figures of the mounted female body and this significantly impedes the correct interpretation of the taxonomic characters. During a revisionary study of the old material, preserved in the collection of the Zoological Institute of the Russian Academy of Sciences, an adult female specimen was discovered and successfully prepared; this specimen matches the descriptions of Green (1922) and Morrison $(1927,1928)$. A redescription and a modern-style figure of the species are provided here based on this specimen.

\section{Hemaspidoproctus cinereus (Green, 1922)}

Fig. 3

\section{Material examined}

INDIA • $q$ adult; Uttar Pradesh, Allahabad; 17 Apr. 1958; N. Alexandrov leg.; on Psidium sp. (Myrtaceae), ZIN RAS, K 1502.

\section{Redescription}

\section{Female}

Adult female in life covered with thick plates of white wax (Fig. 3). Body broadly oval, about $9 \mathrm{~mm}$ long. Antennae 10-segmented, covered with flagellate setae of different thickness. Legs normally developed; trochanter with 3 sensillae on each face; claw without a denticle; claw digitules short, setose. Mouthparts well developed. Thoracic spiracles with spiracularia and groups of small quadrilocular pores, located in notch near each atrium. Abdominal spiracles numbering 7 pairs, located along abdominal margin on dorsum; each abdominal spiracle with unilocular atrium, without wax pores inside or just near spiracular atrium. Anal apparatus poorly visible in the available specimen, but it exactly represented by a short tube with internal sclerotized ring. Seven oval cicatrices present on venter posterior to vulva. Oval and round cuticular pouches of different size forming rows on dorsum and in marginal zone of venter (see Fig. 3). Wax glands represented by four types of discoidal pores: 1) large quadrilocular pores (each about $12 \mu \mathrm{m}$ in diameter) with cuticular duct, scattered on dorsum and forming ovisac band on venter; 2) small quadrilocular pores (each about 9-10 $\mu \mathrm{m}$ in diameter) without cuticular ducts, scattered on venter; 3) trilocular pores (each about 9-10 $\mu \mathrm{m}$ in diameter) - probably modified small quadrilocular pores, occasionally present on dorsum and venter among normal quadrilocular pores; 4) multilocular pores (each about $12 \mu \mathrm{m}$ in diameter), forming group around anal opening on dorsum and group around vaginal opening on venter. Large bitubular glands totally absent. Ovisac band present, formed by large quadrilocular pores. Conical setae very numerous, scattered on all dorsum and on ventral surface of cephalothorax; on dorsum more densely located conical setae additionally forming groups along margin, submargin and midline. Flagellate setae of different size and thickness numerous in medial and submedial zone of ventral cephalothorax and on abdominal sternites. 


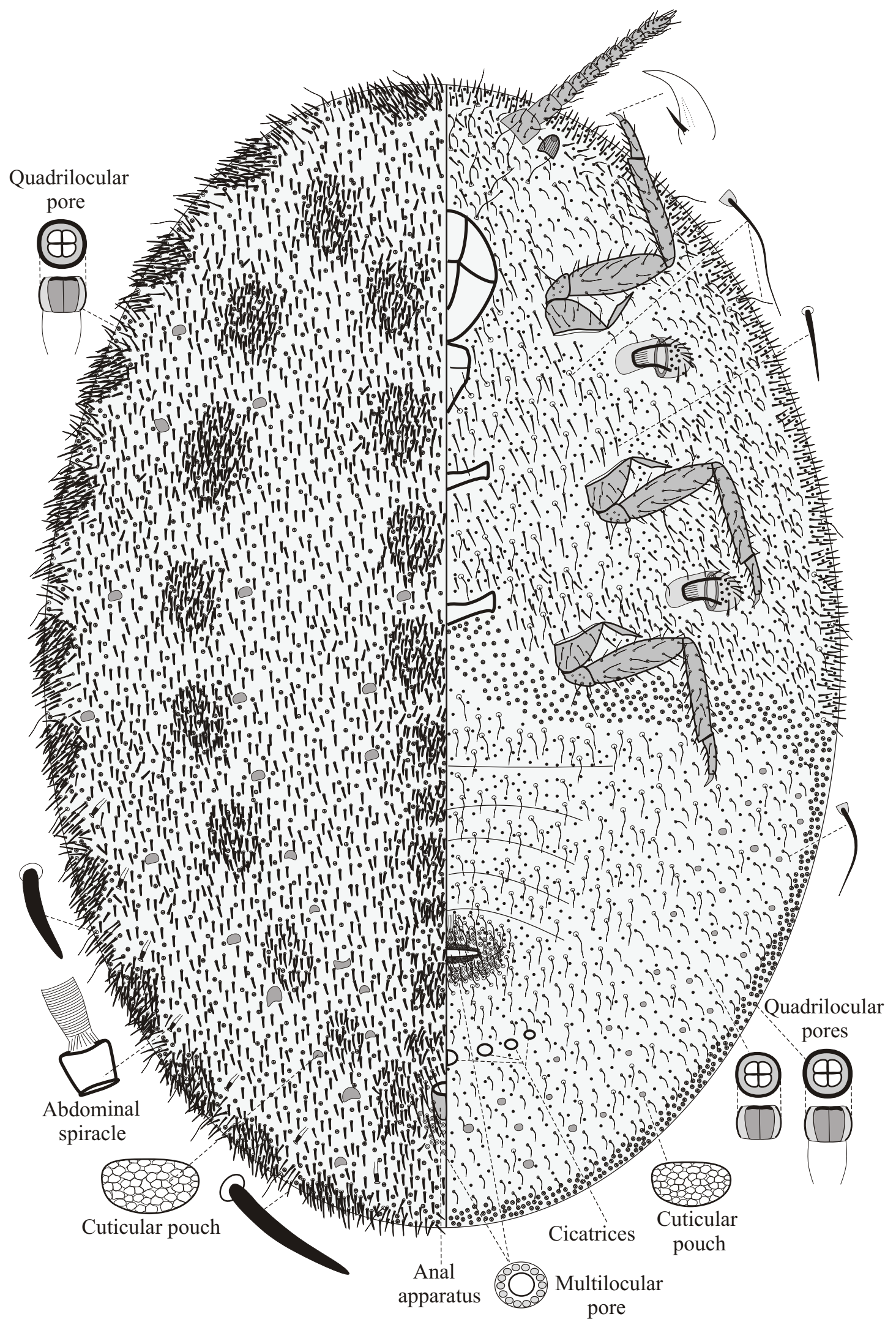

Fig. 3. Hemaspidoproctus cinereus (Green, 1922), comb. nov. Morphology of the adult $q$ from India (Allahabad) (ZIN RAS, K 1502). Not to scale. 


\section{Primolarva}

According to Morrison (1928: 151), the primolarva has 5-segmented antennae; short anal tube with double row of wax pores at inner end, with internal ring of disc pores and with circle of peculiar capitate setae around anal opening; single cicatrix present; quadrilocular pores, multilocular pores and large marginal bitubular glands present; dorsum covered with numerous conical setae.

\section{Adult male and other larval instars}

Unknown.

\section{Remarks}

The type specimens of the species from Sri Lanka and the specimens from India, studied by Morrison (1928: 148), have 3-5 cicatrices, whereas the female, studied by me shows 7 cicatrices.

Hemaspidoproctus tosariensis (Reyne, 1957) comb. nov.

\section{Remarks}

Reyne (1957: 115) described a new species of giant scales, Walkeriana tosariensis, inhabiting Casuarina junghuhniana Miq. in East Java, and placed it in the genus Walkeriana Signoret, 1876 with a doubt. The adult females of this species have an ovisac band of wax glands and form a large ovisac during oviposition in contrast to other species of Walkeriana. Taking this into account, $W$. tosariensis is transferred to the related genus Hemaspidoproctus, whose members, including the type species redescribed above, have the ovisac band and form more or less prominent ovisacs.

Genus Walkeriana Signoret, 1876

\section{Remarks}

Morrison (1928: 143) noted the presence of large bitubular glands in the adult female of Walkeriana florigera (Walker, 1858), the type species of the genus, but he did not illustrated such glands in the appropriate figure (in contrast to all other described morphological structures). Green (1922), describing the same species, didn't mention such glands in the adult female. However, these glands are present in primolarvae of $W$. florigera, according to the descriptions and figures of both authors. According to Green (1922), also the other species of Walkeriana do not have bitubular glands in adult female stage, but only in larvae. Thus, the note of Morrison (1.c.) about the presence of glands in the adult female was probably a mistake. This possible mistake was also reproduced in the key to the genera of Labioproctini (Gavrilov-Zimin 2018: 165). To avoid any misunderstanding in the future, a slightly corrected key to the genera of the tribe is provided here.

\section{Renewed key to genera of the tribe Labioproctini (adult females)}

Based on Gavrilov-Zimin (2018).

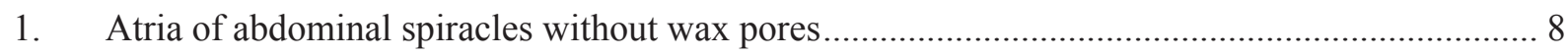

2. Large bitubular wax glands present, forming clusters along body margin. Marsupium present ... 5

3. Cicatrices 3 in number, located posterior to vulva. Oriental Labioproctus Green, 1922

4. Cicatrices very numerous, forming wide band along ventral body margin and transverse rows on abdominal sternites. Afrotropical Aspidoproctus Newstead, 1901 
5. Large bitubular wax glands absent (but may present in larvae). Marsupium absent; eggs deposited under the body or in wax ovisac

6. Ovisac band well developed Hemaspidoproctus Morrison, 1927

7. Ovisac band absent Walkeriana Signoret, 1876

8. Atria of abdominal spiracles with numerous wax pores

9. Marsupium and wide marsupial band present. Cicatrices numerous, forming rows on abdominal sternites Misracoccus Prabhaker Rao, 1950

10. Marsupium and marsupial band absent. Only one cicatrix present

Lecaniodrosicha Takahashi, 1930

\section{Discussion}

Tang \& Hao (1995) erected two new subtribes, Aspidoproctina and Walkerianina in the tribe Monophlebini, but these authors did not provide any characters to separate these subtribes from any previously described taxon of scale insects. In 1995 the tribe Monophlebini included only one subtribe, Monophlebina Signoret, 1875 (according to the Principle of Coordination, Article 36.1 of ICZN), but Tang \& Hao (1995) consciously excluded Monophlebina from the consideration (page 173 in the Chinese text and page 616 in the English translation). So, the names Aspidoproctina and Walkerianina should be considered as unavailable, nom. nud., because these names were proposed in contradiction with the Article 13.1 of ICZN (the-international-code-of-zoological-nomenclature):

\section{"13.1. Requirements}

To be available, every new name published after 1930 must satisfy the provisions of Article 11 and must 13.1.1. be accompanied by a description or definition that states in words characters that are purported to differentiate the taxon".

\section{Acknowledgements}

The work was performed in the frame of RFBR project no. 19-54-18002. The material was mounted as Canada Balsam slides for the collection of the Zoological Institute, Russian Academy of Sciences according to the state project no. AAAA-A19-119020690101-6. I am grateful to Dr D.A. Dmitriev for the consultations in the zoological nomenclature and for the linguistic corrections in the text and to Dr D.A. Gapon for the consultations in Latin grammar.

\section{References}

Burmeister H. 1835. Handbuch der Entomologie. Vol. 2. T.F. Inslin, Berlin. https://doi.org/10.5962/bhl.title.8135

Cockerell T.D.A. 1894. A check list of Nearctic Coccidae. The Canadian Entomologist 26: 31-36. https://doi.org/10.4039/Ent2631-2

Cockerell T.D.A. 1902a. A contribution to the classification of the Coccidae. The Entomologist 35: 232-233. https://doi.org/10.5962/bhl.part.19973

Cockerell T.D.A. 1902b. What is Monophlebus Leach? The Entomologist 35: 317-319.

Danzig E.M. 1980. Koktsydy Dal'nego Vostoka SSSR (Homoptera, Coccinea) s analizom filogenii koktsyd mirovoy fauny. Nauka, Leningrad. [In Russian.] [English edition: Danzig E.M. 1986. Coccids of 
the Far-Eastern USSR (Homoptera: Coccinea). Phylogenetic Analysis of Coccids in the World Fauna. New Delhi.]

Foldi I. 2005. Ground pearls: a generic revision of the Margarodidae sensu stricto. (Hemiptera: Sternorrhyncha: Coccoidea). Annales de la Société entomologique de France 41: 81-25. https://doi.org/10.1080/00379271.2005.10697442

Foldi I. 2016. New archaeococcoids from Guyana and Malaysia, with discussion of the tribes Llaveiini and Drosichini (Hemiptera, Coccomorpha, Monophlebidae). Bulletin de la Société entomologique de France 121 (3): 289-308. Available from https://lasef.org/bulletin-2016-121/ [accessed 27 Mar. 2021].

Gavrilov-Zimin I.A. 2018. Ontogenesis, morphology and higher classification of archaecococcids (Homoptera: Coccinea: Orthezioidea). Zoosystematica Rossica Supplementum 2: 1-260.

https://doi.org/10.31610/zsr/2018.supl.2.1

Green E.E. 1922. The Coccidae of Ceylon, Part V. Dulau \& Co., London. https://doi.org/10.5962/bhl.title.8551

Guérin-Méneville F.E. 1827. Dictionnaire classique d'histoire naturelle. Tome 11. Rey et Gravier Libraires-Éditeurs, Paris. https://doi.org/10.5962/bhl.title.33901

Hempel A. 1920. Descripçoes de coccidas novas e pouco conhecidas. Revista do Museu Paulista (São Paulo) 12: 329-377.

Koteja J. 1974 Comparative studies on the labium in the Coccinea (Homoptera). Zeszyty Naukowe Akademii Rolniczej w Warszawie, Rozprawy Nankowe 89: 1-162.

Koteja J. 2000. Advances in the study of fossil coccids (Hemiptera: Coccinea). Polskie Pismo Entomologiczne 69: 187-218.

Morrison H. 1927. Descriptions of new genera and species belonging to the coccid family Margarodidae. Proceedings of the Biological Society of Washington 40: 99-109.

Morrison H. 1928. A classification of the higher groups and genera of the coccid family Margarodidae. United States Department of Agriculture Technical Bulletin 52: 1-239

Reyne A. 1957. Walkeriana tosariensis, a new monophlebine coccid from Casuarina junghununiana Miq. in east-Java. Beaufortia 6: 115-145.

Reyne A. 1965. Observations on some Indonesian scale insects. Tijdschrift voor Entomologie 108: 145188. Available from https://www.biodiversitylibrary.org/page/28271610\#page/189/mode/1up [accessed 27 Mar. 2021].

Vayssière P. 1932. Monophlebines et pseudococcines de l'Afrique du Nord [Hem. Coccidae]. Bulletin de la Société entomologique de France 37: 24-28.

Available from https://www.persee.fr/doc/bsef_0037-928x_1932_num_37_2_14365 [accessed 27 Mar. 2021].

Westwood J.O. 1845. Plate VI. Illustrations of various species of Coccidae, belonging to the genus Monophlebus. Arcana Entomologica 1: 21-22. https://doi.org/10.5962/bhl.title.11771

Tang F.T. \& Hao J.J. 1995. The Margarodidae and Others of China. Chinese Agricultural Science Technology Press Beijing, P.R. China. [In Chinese, with English summary.]

Williams D.J. 1969. The family-group names of the scale insects (Hemiptera: Coccoidea). Bulletin of the British Museum (Natural History), Entomology 23: 315-341. https://doi.org/10.5962/bhl.part.15136 
Manuscript received: 23 July 2020

Manuscript accepted: 9 February 2021

Published on: 19 April 2021

Topic editor: Nesrine Akkari

Desk editor: Pepe Fernández

Printed versions of all papers are also deposited in the libraries of the institutes that are members of the EJT consortium: Muséum national d'histoire naturelle, Paris, France; Meise Botanic Garden, Belgium; Royal Museum for Central Africa, Tervuren, Belgium; Royal Belgian Institute of Natural Sciences, Brussels, Belgium; Natural History Museum of Denmark, Copenhagen, Denmark; Naturalis Biodiversity Center, Leiden, the Netherlands; Museo Nacional de Ciencias Naturales-CSIC, Madrid, Spain; Real Jardín Botánico de Madrid CSIC, Spain; Zoological Research Museum Alexander Koenig, Bonn, Germany; National Museum, Prague, Czech Republic. 